\title{
Effects of Pre-Announced Product Characteristics on Customer's Purchase Intention
}

\author{
Rashid Zaman (Corresponding Author) \\ MPhil (Management Sciences) \\ Bahria University Islamabad, Pakistan, PO box 440000, E-8, Islamabad, Pakistan \\ Email: rashidzamantanoli@yahoo.com \\ Muhammad Arslan \\ MPhil Scholar \\ Bahria University Islamabad, Pakistan, PO box 440000, E-8, Islamabad, Pakistan
}

\begin{abstract}
The purpose of this paper is to analyze that which attributes of NPP effect on the customer decision-making regarding the purchase intention of the customer. As in the customer decision making process, persuasion stage have most influencing effect in which the attributes of the new product seems to be have a strong impact on the purchase intention; this paper aims to empirically verify the effects of the attributes of the new product on the customer's purchase intention for the new preannounced product. Adopted questioners were used as primary source for data collection and cross tabulation method is used to analyze the data. The finding of this paper shows the positive impact of relative advantage, compatibility, obserbility and triablity on the customer's purchase intention while the complexity has the negative relation to the purchase intention. By having these aspects in view it will be helpful to get succeed the new product. This paper provide a framework that how new products can be more successful and more quickly diffused in the market and let consumers to post pond their needs until the arrival of the product. This can also be helpful to increase the percentage of the innovators in the diffusion cycle of the innovation.
\end{abstract}

Keywords: - Diffusion of Innovation, Consumer Behavior, Preannouncement, Advertisement, and compatibility

\section{Introduction}

Declaration of the arrival of a new product is said to be as New Product Preannouncement (NPP). Some people know NPP as advertising and product positioning, in which companies send messages to the market about their new product. In Pakistan, film industry uses it, as before releasing a movie start advertising about the movie and make people aware of it. Like film industry, software and telecom industry are also using this strategy. Companies use NPP, just for keeping their potential customers away from buying their competitive products and suppose that customer will post pond his purchase until the arrival of their product (Bayus, et al 2001).NPP is used as the communication tool with the market.

Many researchers have made contribution in NPP in which; whether to preannounce(Eliash berg \& Robertson, 1998) when to preannounce, timings (Lilly \& Walters, 1997),impact of vaporware and customer exception and vendor reputation (Garsombke \& Garsombke.H.P, 1998), vaporware and pre anouncement, truth and concequences(Bayus, et al., 2001), preannouncement effects on the stock price and earning(Miller, 2005), preannouncement behavior on new product launch(Schatzel \& Calantone, 2006), preannouncing pioneers vs follwers; what message should(Homburg, et al 2009), NPP as signal theroy (Su \& Rao, 2010), Effect of preanouncement on purchase intention (Zhang \& $\mathrm{Su}, 2011$ ).

Considering the literature of NPP, many people do excessive work. To make the NPP effective, timings of the NNP which matters a lot with the product? When companies after pre announcing don't launch the product at time are came in vaporware, how companies encounter the vaporware in order to establish their reputation in the market. The introduction of the new product with the economical conditions and announcing through the signal theory is known as NPP. Most literature of NPP are on the firms, competitors and distributors; what message should be in NPP and how it effect to different peoples. NPP can be beneficial only if customers perceive that new product compatible with them.

Little research found on customer's intention about the new product, as the customers are the most important segment of the NPP and success of new product is also dependant on the customer's point of view.

A little gap exists between the customers point of view; the innovation attributes on NPP exists, and to fill this gap our study is providing a empirical framework to make understanding of the innovative product attributes (Relative Advantage, Compatibility, Complexity, Triability and Obserbility) on the customer's purchase intentions about the New Preannounced Product; and also explaining the how NPP can be perceived as the success of innovation. This paper is consist of different sections; Introduction, Literature Review, theoretical model, research methodology and conclusion. 


\section{Literature Review}

\subsection{New Product Pre announcement (NPP)}

New product announcement (NPP) is product related news used to inform customers about the arrival of the new product. NPP is defined as "formal, deliberate communication before a firm actually undertakes a particular marketing action such as a price change, a new advertising campaign, or a product line change." (Eliash berg \& Robertson, 1998). Most of the industries in the market are now using NPP e.g softwares, film indusrty and telecomunication industry etc. In USA $50 \%$ of the companies use NPP while introducing the new product (Bayus, et al 2002).NNP has the great impact on the maket anticipation with the market participants (buyers, distributers,suppliers,investors etc) and are positively related to the new product sucess (Schatzel \& Calantone, 2006).Markte partcipants value more to that preannounced products which have evidences of product attributes and arrival (Bharbra, et al 2001).

\subsection{Signal Theroy}

For announcing new product companies use different tools, which tell the market about the intentions of the company. Most effective tool for pre announcing is signal theroy,in which companies send signal to their customer,competitors and the market about their product.In marketing point of view people consider it as advertising or positioning. Signaling theroy have two main aspects; Signal sender; the person or company who is sending any news or signal about any thing. Signal receiver ; the person or company who is receiving the signal or news from sender side.

\subsection{Innovation}

Innovation is a term originated from initials, persons who like to use the new product are said to be as innovators and that product with new attributes are said to be as a innovation. Innovation is any idea or practice that is considered new by the customers or the market(Rogers, 1995). Whenever any innovation comes in the market, companies focus to tell customers about innovation. So that people aware of that innovation and go for purchase. The rate by which innovation spreads is said to be diffusion of innovation. (Rogers, 2003).Innovation is communicated by the means of different communication channels among the customers, in order to build the knowledge about the innovation.Many research has been conducted to invetigate that what variables can influnce the innovation behaviour of the customers or the product it self. How innovation is assesed by different peoples and how people preceive innovativeness? (Blythe, 1999).Relationship of consumer innovatiness on the internet ,its attitudes and online banking adoptaion(Lassar, et al 2005).Examination of consumer innvativeness and perceived risk in new product adoption (Hirunyawipada \& Paswan, 2006).Proposal for the set of coping strategies which interact with the decision making of adoption or unadoption of innovation (Cui.G, et al 2009).Innovativeness and shoping styles(Park, et al 2010). These studies help to understand the innovativeness and its impacts on consumers.In the decision making process of innovation, first knowledge about innovation in which customer get aware of innovation, information on the basis of the customer variables like personality traits,social factors and customer novelty seeking.At the basis of knowledge ,persuation stage stage comes in which attributes of innovation like relative advantage, complexity, compatibility,observebilty and triability persue customers to purchase.Past researches explaine customer innovative characteristics leads customer to buy new prouct, but (Park, et al., 2010) argues that two types of behavioural customer innovativeness have different aspects , cognative innovatiness leads customer to look on the utilitarian features of the product whereas sensory innovatiness leads customer to look on the aestheic aspect of the product.As time passes consumers are having emphases more on the product innovatines while on the behaviourval innovative trait.Roger characterized innovation into five aspects to determine are as follows;

\subsubsection{Relative Advantage}

It is something which customers think superior than other and preceive it more benefical.Any innovation that considered better than the other, it can better in terms of social ,economic,status and self- esteem (Rogers, 1995).Innovation with more relative advantage spreads more quickly and customers feel confident to use it.Now a days customers like to use the products which are more benefical.Innovation is categorized into two aspects; preventive and incremental (non-preventive) innovations(Rogers, 2003).Preventive means a complete new product with means of all new attributes, its adoption rate is slow and customers also think that less benefical relative to others, while incremental means some changes in exsisting product, customers preceive it more benefical as they can easily compare that with earlier product before changes and can easily see difference between these two.Relative advantage of incremental innovation is more certain than preventive. Relative advantage is also depend on the situations, where the other options don't work and you have a opportunity to act thats also your realative advantage of the product using that time (Mallat, et al 2006).Customer satisfaction is positively related to the realative advantage and also on the product intelligence (Rijsdjk, et al 2007).Frims which introduce a new product different from the earlier product have a relative advantage over others due to the differences among them (Choi.J.P, et al 2008).Pre announcements that focuses on the relative advantage of the product lead towards the sucess of product at its arrival (Homburg, et al 2009 ). 


\subsubsection{Compatibility}

Compatibility refers an innovation to be compatible with the existing values. It is the degree to which innovation is perceived as relevant with the values, norms and needs of the present (Rogers, 2003).Innovation that is more compatible with existing values are considered as faster adoption. People feel more confident of using that innovation which is compatible with their needs and wants (Wungwanitchakorn \& A, 2002). Internet user perceive self-service technology as compatible with them (Gerrard.J \& Cunningham.J.B, 2003). People not only like new products just because of its newness but because they are compatible with them (Rijsdijk.S.A \& Hultink.E.J, 2007). The product which is compatible with the values and norms of the customers have a higher rate of adoptation ( $\mathrm{Lu} \& \mathrm{Su}, 2009)$. Some people consider compatibility as same of relative advantage, while they are different as relative advantage is something beneficial than other; while compatibility is resemblance of current values.

\subsubsection{Complexity}

How much complex is a innovation or in other words at what extend innovation is easy to use. The degree to which an innovation is perceived easy to use and understand (Rogers, 1995).Innovation that is less complex have a high rate of adoption, as it's a human psychology to resist change .People don't want to learn new things and feel comfortable of using existing things. Complexity has the significant effect on the learning requirement of the customer of $10 \%$ (Wungwanitchakorn \& A, 2002). Consumers who are familiar with the technology used in new product, don't face complexity issue, because once consumer will go through the technology then he will be familiar and perceive that easy (Gerrard.J \& Cunningham.J.B, 2003).Consumers that perceive the innovation easy to use, will more likely possible to adopt the innovation (Changa, et al 2005a).IT based product are considered more complex, and mostly have the negative impact on the customer satisfaction, just because of the unawareness of the new technology (Rijsdijk.S.A \& Hultink.E.J, 2007).To be compatible with needs of the customers leads towards the positive intention for the purchase of the new product. Products that are easy to use by the customers are perceived useful, and customer's intention of purchasing will enhance ( $\mathrm{Lu} \& \mathrm{Su}, 2009$ ).

\subsubsection{Traiability}

The degree to which an innovation is experienced on some basis (Rogers, 1995).Nobody has enough money to spend on the product which can't be even checked before. Let customers try the new product, because on the basis of this a will for buying of that product can b produced in the customers. Customer learning is dependent on the triablity of the product and as customer learn more he will have more intentions for purchasing (Wungwanitchakorn \& A, 2002).

\subsubsection{Obserbility}

Obserbility of innovation means that how much innovation is view in routine.(Rogers, 2003) explains Obserbility as the degree to which an innovation is visible to peoples. As more innovation will be visible to others as more adoption of that innovation will be. While seeing the innovation give customer confidence to use that innovation as obserbility lead customer to think about adaptation and create a reason to adopt that in mind. As new product be more visible among the consumer and the market people will more likely to get aware of that and will be able to get more knowledge about the product. Once people will get the knowledge about the product then they are more convinced to buy the product as the knowledge decreases the consumer dissonance about the product and lead him to buy that product.

\section{Theoretical Model}

Introducing the NPP, characteristics of the innovated product has an important impact on it. As in NPP stage, companies are introducing products and having a look on these characteristics will influence positive impact on the customer purchase intention for NPP. In this study our independent variables are relative advantage, complexibility, compatibility, Obserbility and Triability and consumer purchase intention is our dependent variable .All the characteristics of NPP have significant impact on the consumer purchase intention(Rogers, 1995).

Fig 1: - Model for Determining Characteristics of Innovation on NPP Purchase Intention.

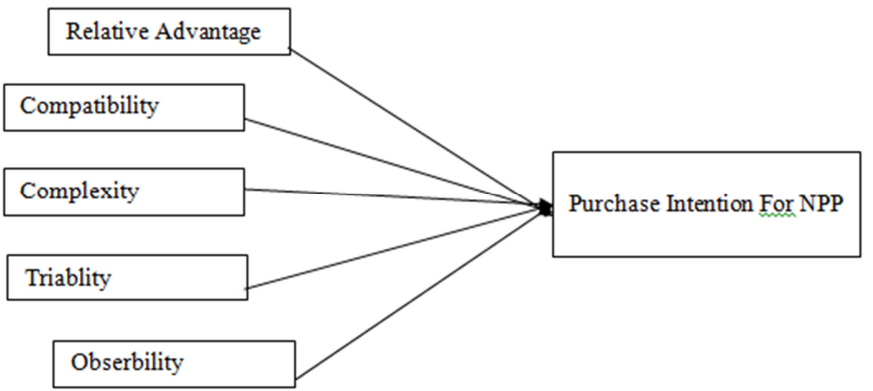

Adopted from Literature 


\subsection{Hypothesis Development}

The literature concludes that the positive impact of relative advantage, compatibility, Obserbility and Triability on the customer's purchase intention while the complexity has the negative relation to the purchase intention. From literature we concluded the following hypothesis

H1: Relative Advantage is positively related on the purchase intention of NPP.

H2: Compatibility is positively related on the purchase intention of NPP.

H3: Complexity is negatively related on the purchase intention of NPP.

H4: Triability is positively related on the purchase intention of NPP.

H5: Obserbility is positively related on the purchase intention of NPP.

\section{Research Methodology \\ 4.1 Sample Size}

It is well establish from the literature that New Product characteristics had influence on consumer purchase intension. To empirically investigation of our developed hypothesis, adopted questioner has been distributed to the sample of 180 respondents of multidiscipline. 150 questioners feedback was obtained. Different dimension of NPP are compared with education level.

Table 1. Concludes that $81 \%$ respondent consider that relative advantage have the significance influence on their purchase intention. Relative advantage has the positive impact on the customer purchase intention, the advantage which a product have on the other product that can be of functional, life style, value and status perspective. People perceive these things, as relative advantage and company while announcing the product must have to identify the customers about the relative advantage of the product in means of direct or indirect manner. They give preference to that product which has some advantage over others, verifying our hypothesis $\mathrm{H} 1$ that relative advantage is positively associated with consumer purchase intension. Our result is in line with the previous literature (Homburg, et al., 2009 ).

Table 2. Concludes that $85 \%$ of the respondent from different level of education response positively that they give preference to that product which they have tried or test before. Online software and many other things have the trial period for customer so that he can able to understand the product and its feature so this phenomenon of traiability is positive associated with the consumer purchase intension. Triability gives customer confidence to use that product and positively related on the purchase intention for the preannounced product. Triability also Enables Company to see the results of their new product whether they are accordingly as they are expecting otherwise they have chance to improve that product in the manner in which customers are demanding. Our finding is in line with the study of (Wungwanitchakorn \& A, 2002). In which they suggest that customer learning is dependent on the triablity and as customer learn more he will definatley purchase it more.

Table 3. Represent the result of complexity characteristic of NPP with consumer purchase intention. When the selected respondents were asked; whether they prefer to buy the complex things with new feature or the innovative product, which characteristics are not known to them. The majority of respondent responded in negative way that they will not buy that innovative product which characteristic they seem difficult in use or having complex.94\% are in favor of not buying such type of product. The relationship between the complexity and consumer purchase intention is negative. Customers always like that product which is easy to use and have positively related to the purchase intention. The product, which is complex in use, customers most like to avoid the use of that product. Results of table 6 are in line with the studies of past researcher. Consumers that perceive the innovation easy to use, will more likely possible to adopt the innovation (Changa, et al 2005b).IT based product are considered more complex, and mostly have the negative impact on the customer satisfaction, just because of the unawareness of the new technology (Rijsdijk.S.A \& Hultink.E.J, 2007).

Table 4 shows the result of compatibility with consumer purchase intention. When the respondent was asked whether they consider ethical values in purchasing a innovative product. $60 \%$ of total sample respondent says yes that they consider these things.30 \% don't consider thing they will just buy things with their own use and $10 \%$ are intermittent about the social value in purchasing. The products, which are more compatible with the customer values, have more intentions towards the purchasing of the product. As customers want things that are compatible with them and their values because often usage of a product that are not compatible with their values leads them to the by coat of their social members Crosstab result for the compatibility chractersitc of NPP product in relation to purchase intention suggests that our hypothesis H4: that compatibility is positively related with the consumer purchase intention and also in line with Rijsdijk.S.A \& Hultink.E.J, (2007) and Gerrard.J \& Cunningham.J.B, (2003).

Table 5. shows that the $85 \%$ of the total respondent was in favor, when asked to purchase the product by talking about of other people. It shows how the people inspire from the opinion of other people for the use of innovative product. As new product be more visible among the consumer and the market people will more likely to get aware of that and will be able to get more knowledge about the product. Once people will get the knowledge about the product then they are more convinced to buy the product as the knowledge decreases the 
consumer dissonance about the product and lead him to buy that product.

\section{Conclusion}

Through the above studies it is empirically concluded that these characteristics of innovation (Rogers, 2003); relative advantage, compatibility, complexity, triablity and observbilty have the impact on the customers purchase intention as these are used to pursue the customer in the decision making process. In these relative advantage, compatibility, triablity and obserbility have the positive effect on the customers purchase intention while only complexity have the negative effect on the purchase intention of the customer as customers don't like to get in trouble by the use of the new product. Customers for the new preannounced product look at these characteristics and that will influence the intentions of the customer's purchasing. By looking on these characteristics company can diffuse their innovation more rapidly and can enhance the innovators rate, which will give them to get succeed in the term of new product. The sample size of our study is small due to time constraint.

\section{References}

Bayus, B. L., Jain, S., \& Rao, A. G. (2001). Truth or consequences: an analysis of vaporware Journal of Marketing Research, 38(1), 3-13.

Bhabra.H.S, \& Mishra.D.P. (2001). Accessing the economic worth of new product preannouncement signals:theroy and emperical evidence. Journal of Product \& brand Management 10 (2), 75-93.

Blythe, J. (1999). Innovativeness and newness in high-tech consumer durables. journal of product \& brand management 8(5), 415-429.

Changa, M. K., Cheungb, W., \& Laib, V. S. (2005a). Literature derived reference models for the adoption of online shopping. Information \& Management, 42, 543-559.

Changa, M. K., Cheungb, W., \& Laib, V. S. (2005b). Literature derived reference models for the adoption of online shopping. Information \& Management, 42, 543-559.

Choi.J.P, Kristiansen.E.G, \& Nahm.J. (2008). Strategic Product Preannouncements in Markets with Network Effects. working paper.

Cui.G, Bao.W, \& Chan.T. (2009). Consumers' adoption of new technology products: the role of coping strategies. Journal of Consumer Marketing, 26(2), 110-120.

Eliash berg, J., \& Robertson, T. S. (1998). New Product Preannouncing Behavior: a Market Signaling Study. Journal of Marketing Research, 25(3), 282-292.

Garsombke, F. D., \& Garsombke.H.P. (1998). The impact of vaporware, reliable software, vendor dependence and fulfilled promises on customers' perceptions/experiences and vendor reputation. Software Quality Journal, 7, 149-173.

Gerrard.J, \& Cunningham.J.B. (2003). The diffusion of internet banking among Singapor consumers. International Journal Of Banking Marketing, 21(1), 16-28.

Hirunyawipada, T., \& Paswan, A. K. (2006). Consumer innovativeness and perceived risk:implications for high technology product adoption. Journal of Consumer Marketing, 23(4), 182-198.

Homburg, C., Bornemann, T., \& Totzek, D. (2009). Preannouncing pioneering versus follower products:what should the message be? . Academy of Marketing Science, 37, 310-327.

Homburg, C., Bornemann, T., \& Totzek, D. (2009). Preannouncing pioneering versus follower products:what should the message be? . Academy of Marketing Science, 37, 310-327.

Lassar, W. M., Manolis, C., \& Lassar, S. S. (2005). The relationship between consumer innovativeness,consumer innovativeness,online banking adoption. International Journal Of Banking Marketing, 23(2), 176-199.

Lilly, B., \& Walters, R. (1997). Toward a Model of New Product Preannouncement Timing. Journal of Product Innovation Management, 14, 4-20.

Lu, H.-P., \& Su, P. Y.-J. (2009). Factors affecting purchase intention on mobile shopping web sites. . Internet Research Journal, 19(4), 442-458.

Lu, H.-P., \& Su, P. Y.-J. (2009 ). Factors affecting purchase intention on mobile shopping web sites. Internet Research Journal, 19(4), 442-458.

Mallat, N., Rossi, M., Tuunaine, V. K., \& rni, A. O. o. (2006). An empirical investigation of mobile ticketing service adoption in public transportation Pers Ubiquit Comput, 12, 57-65.

Miller, J. S. (2005). Effects of Preannouncements on Analyst and Stock Price Reactions to Earnings News. Review of Quantitative Finance and Accounting, 24, 251-275.

Park, J. E., Yu, J., \& Zhou, J. X. (2010). Consumer innovativeness and shopping styles. Journal of Consumer Marketing. Journal of Consumer Marketing, 27(5), 437-446.

Rijsdijk.S.A, \& Hultink.E.J. (2007). Product intelligence: its conceptualization, measurement and impact on consumer satisfaction. journal of Academy of Marketing Science, 35, 340-356. 
Rogers, E. M. (1995). Diffusion of Innovation:. New York London Toronto Sydney.

Rogers, E. M. (Ed.). (2003). Diffusion of innovation (Fifth Edition ed.). New york: The Free Press.

Schatzel, K., \& Calantone, R. (2006). Creating Market Anticipation:An Exploratory Examination of the Effect of Preannouncement Behavior on a New Product's Launch. . Journal of the Academy of Marketing Science, 34(3), 357-366.

Su, M., \& Rao, V. R. (2010). New Product Preannouncement as a Signaling Strategy: An Audience-Specific Review and Analysis. Journal of Product Innovation Management 27, 658-672.

Wungwanitchakorn, \& A. (2002). Adoption Intention of Banks' Customers on Internet Banking Service. ABAC Journal, 22(3), 63 - 80.

Zhang, L., \& Su, M. (2011). Effect of NPP on purchase intention; from customer perspective. Nankai Business Review International, 2(1), 48-63.

Table 1:Relative advantage * Education Cross tabulation

\begin{tabular}{|ll|l|l|l|l|}
\hline & \multicolumn{2}{|l|}{ Education } & \multirow{2}{*}{ Total } \\
\cline { 2 - 5 } & & Diploma & UG & PG & 122 \\
Relative advantage & yes & 10 & 63 & 49 & 28 \\
& no & 3 & 11 & 14 & 150 \\
\hline
\end{tabular}

Table 2: Traiability * Education Cross tabulation

\begin{tabular}{|ll|l|l|l|l|}
\hline \multirow{2}{*}{} & \multicolumn{2}{|l|}{ Education } & \multirow{2}{*}{ Total } \\
\cline { 2 - 5 } & Diploma & UG & PG & 127 \\
Triability & yes & 10 & 65 & 52 & 23 \\
\multirow{3}{*}{ Total } & 3 & 9 & 11 & 150 \\
& 13 & 74 & 63 & & \\
\hline
\end{tabular}

Table 3 Complexity * Education Cross tabulation

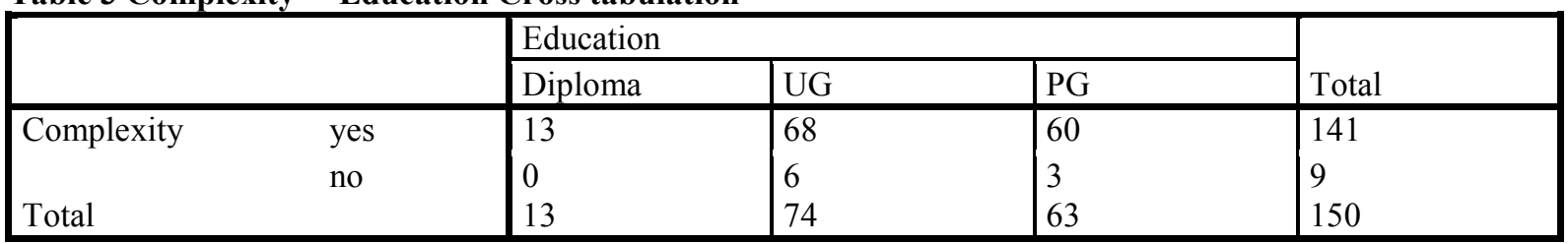

Table 4:Compact ability * Education Cross tabulation

\begin{tabular}{|ll|l|l|l|l|}
\hline & \multicolumn{2}{|l|}{} & \\
\cline { 2 - 4 } & & Education & PG & Total \\
\hline Compact ability & yes & 7 & 33 & 31 & 71 \\
& no & 6 & 41 & 32 & 79 \\
Total & 13 & 74 & 63 & 150 \\
\hline
\end{tabular}

Table 5:Obserability * Education Cross tabulation

\begin{tabular}{|ll|l|l|l|l|}
\hline & & \multicolumn{2}{|l|}{} & \\
\cline { 3 - 5 } & & Education & PG & Total \\
\hline Obserability & yes & 10 & 64 & 49 & 123 \\
& no & 3 & 10 & 14 & 27 \\
Total & 13 & 74 & 63 & 150 \\
\hline
\end{tabular}


The IISTE is a pioneer in the Open-Access hosting service and academic event management. The aim of the firm is Accelerating Global Knowledge Sharing.

More information about the firm can be found on the homepage:

http://www.iiste.org

\section{CALL FOR JOURNAL PAPERS}

There are more than 30 peer-reviewed academic journals hosted under the hosting platform.

Prospective authors of journals can find the submission instruction on the following page: http://www.iiste.org/journals/ All the journals articles are available online to the readers all over the world without financial, legal, or technical barriers other than those inseparable from gaining access to the internet itself. Paper version of the journals is also available upon request of readers and authors.

\section{MORE RESOURCES}

Book publication information: http://www.iiste.org/book/

\section{IISTE Knowledge Sharing Partners}

EBSCO, Index Copernicus, Ulrich's Periodicals Directory, JournalTOCS, PKP Open Archives Harvester, Bielefeld Academic Search Engine, Elektronische Zeitschriftenbibliothek EZB, Open J-Gate, OCLC WorldCat, Universe Digtial Library, NewJour, Google Scholar

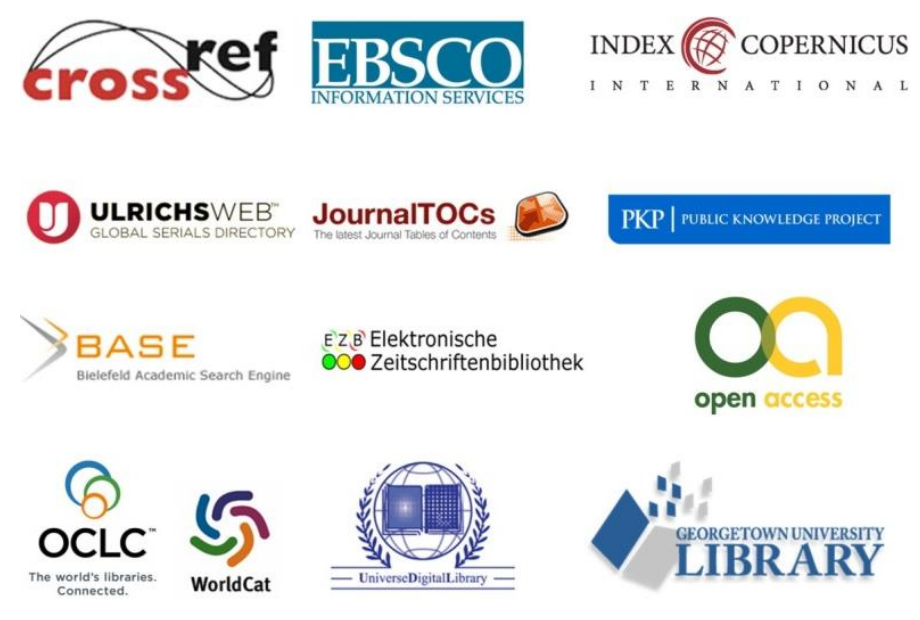

